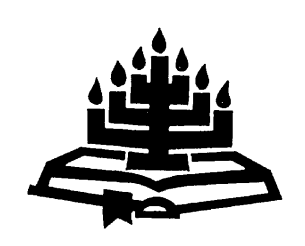

\title{
The contribution of deontological Christian ethics to the contemporary human rights discourse
}

\author{
J.M. Vorster \\ School for Ecclesiastical Sciences \\ Potchefstroom Campus \\ North-West University \\ POTCHEFSTROOM \\ E-mail: Koos.Vorster@nwu.ac.za
}

\begin{abstract}
The contribution of deontological Christian ethics to the contemporary human rights discourse

This article examines the possible role of a Christian deontological ethics in the contemporary human rights debate. It concludes that a Christian deontological ethics in the Reformed tradition can be positively engaged in the human rights debate when Biblical theological topics are transposed into moral directives applicable to the current human rights concerns, such as religious extremism, femicide, ideologies of intolerance and ecocide. As an example of the applicability of a Christian deontological ethics from a reformed perspective, the following Biblical topics are investigated: human dignity on the basis of the "imago dei", creation and creational integrity, the kingdom of God and forgiveness. Furthermore, the article proposes that other concepts can be added to this list such as the Biblical idea of life, eschatology, covenant and holiness.
\end{abstract}

\section{Opsomming}

\section{Die bydrae van 'n deontologiese Christelike etiek tot die hedendaagse menseregtedebat}

Hierdie artikel gee aandag aan die moontlike rol wat 'n Christelike deontologiese etiek kan speel in die huidige menseregtediskoers. Die artikel kom tot die gevolgtrekking dat 'n deontologiese Christelike etiek uit die reformatoriese tradisie effektief betrokke kan wees by hierdie debat wanneer Bybelse konsepte getransponeer kan word in etiese beginsels wat toepaslik kan wees in huidige menseregte problematiek soos godsdiensek- 
stremisme, onderdrukking van die regte van die vrou, ideologieë van onverdraagsaamheid en die vernietiging van ekosisteme. As 'n voorbeeld van die toepaslikheid van 'n deontologiese Christelike etiek uit die reformatoriese tradisie in hierdie verband, word die volgende Bybelse temas getransponeer: menswaardigheid op die basis van die "imago dei", die skepping en die integriteit van die skepping, die koninkryk van God en vergiffenis. Die artikel stel verder voor dat ander Bybelse konsepte getransponeer word soos die Bybelse konsep van lewe, eskatologie, die verbond en heiligheid.

\section{Introduction}

The agendas of the Human Rights Council of the United Nations over the past decade reveal an alarming escalation of macro ethical problems in the contemporary human rights environment. Phenomena such as the detrimental effects of globalisation, violation of the human rights of women, migration with subsequent xenophobia and the rise of religious extremism and violence pose huge challenges to the ethical discourses in this domain. Deontological Christian ethics of all the main Christian traditions are also confronted with these major challenges. Is deontological Christian ethics equipped to provide answers to the many questions facing modern societies in the contemporary human rights discourse? Or can deontological Christian ethics, and, as a matter of fact, Christian theology as a whole, only be of value when it is secularised and liberated from its metaphysical character as Cuppitt (1999:218) pleads for?

In this article, I deal with these questions and argue that deontological Christian ethics in the reformed tradition is relevant in the contemporary human rights discourse exactly because of its deontological character. 1 The emerging ethical problems reveal that the "rights based" utilitarian ethics that typified the human rights discourse of the past 50 years, failed in nurturing an ethos of human responsibilities and left society with a quest for new moral standards. Deontological Christian ethics can respond to the quest when Christian theologians succeed to transpose the grand themes of a Christian ethics to the socio-political domain.

The argument develops in three stages. First of all I will focus on the main tenets of the contemporary human rights environment. Se-

1 A Christian theory of human rights will not be discussed in this article. I presented my views on this topic in an earlier book. (See Vorster, 2004:85-104.) 
condly the current state of deontological Christian ethics will be addressed and lastly I will attempt to transpose some major themes of Christian ethics to indicate how deontological Christian ethics can develop valid and useful answers for modern society.

\section{The contemporary human rights environment}

The meetings of the Human Rights Council of the United Nations over the past decade revealed four areas of continuous concern. Although many other abuses of human rights are under scrutiny, these four are constantly highlighted by the reports of the special rapporteurs on violations in these fields. These areas of concern are religious extremism, femicide, ideologies of intolerance and ecocide. For the sake of the discussion a short overview of each of these is necessary.

The surge in religious extremism is of major concern because of its destructive effects on peace and social stability. The first decade of the 21st century will, among others, be remembered for the renewed interest in religious extremism. Antoun (2001:153) a contemporary investigator of extremism explains in his book that extremism is flourishing at the beginning of this century.

Scholars working on "The Fundamentalism Project" indicate how extremism is currently alive in Protestantism, Roman Catholic Christianity, Islam, Jewish Zionism, Hinduism, the Sikh Religious Tradition, Buddhism, and Confucianism and in Japanese religions (Marty \& Appleby, 1991:vi). Religious extremism indeed became a focal point of attention. This is not only because of its disturbing influence on peace but also because of its inclination to the violation of human rights and its threat to democracy at large.

The reason for the current attention to the phenomenon is because of the terrorism and violence caused by the emerging Islamic extremism and the reaction in the West. The events of $9 / 11,7 / 7$, the resulting wars in Afghanistan and Iraq and the acts of terrorism in Tanzania, Kenya, Turkey, Indonesia and Spain focused the attention of the world and of many scholars in various fields in the human sciences on the resurging Islamic extremism. Although Huntington (1996:217) maintains that the underlying problem for the West is not Islamic extremism but Islam itself, the overwhelming evidence provided by scholars in the fields of theology, sociology and politics indicate that Islamic extremism has become a major threat to peace today - a threat not posed by moderate Muslims (Vorster, 2008:1). 
A second area of concern which is partly related to the surge in religious extremism is femicide. Femicide is a term used not only for the actual killing of females, but also as an indication of all forms of violence, both physical and pschycological, against them, and which result in social inequality, poverty, hopelessness and despair. The inequality of women was historically ascribed to patriarchal structures. The twentieth century has seen the systematic rectification of the human rights of women in social institutions and in society at large. This process culminated, among others, in two important documents of the United Nations. These are the Vienna Declaration of 1983 and Beijing Declaration of 1995. These documents address the remnants of the old patriarchal societies in the modern world with clear statements on gender equality in all spheres of life, the rejection of all forms of violence against women, the right of women to enjoy the highest standard of physical and mental health and the responsibility of governments to ensure the full implementation of the human rights of women and of girl-children as an inalienable, integral and indivisible part of all human rights and fundamental freedoms (United Nations, 1996:106, 137).

Nevertheless, scholars in this field must concede that these noble principles have still not been achieved in many societies at the beginning of the 21st century. Recent studies about the violation of the human rights of women reveal the presence of various cultural practices where women are ill-treated and condemned to illiteracy and poverty through customs (Vorster, 2004:177). What concerns religious ethics particularly is the fact that the deeper roots of these cultural customs are inter alia to be found in religious convictions and especially religious extremism. Camp (1990:506) articulates the viewpoints of many sociologists and theologians with his conviction that religion can be seen as undoubtedly the most important shaper and enforcer of the image and role of women in culture and society. Many of the modern-day abuses of the human rights of women are rooted thus in a particular religious perspective of gender, namely that men are superior and that women, because of their inferiority, need not have access to education, development and economic activity.

Three manifestations of the violation of the human rights of women due to religious extremism are worthwhile to mention in this regard. Firstly, one can refer to its manifestation in Christianity. In the Western world with its historical Christian ethos, it is often accepted that the human rights of women have been normalised. However, this is still not the case because in the part of Western culture 
associated with Christianity, many blatant forms of gender inequality and the dehumanisation of women can still be discerned. The exploitation of women and young girls in pornography, prostitution networks and human trafficking are some examples of the abuse of women. The commercial utilisation of sexuality in advertising, the press, the cinema and publishing makes women, reduced to bodies, a commodity and a consumer product (Geraudy, 1990:55). In the Western societies violence against women and discrimination in the working place are still alive. Violent attacks on women requiring hospitalisation are the most frequently reported crimes throughout the United State's cities - the attacks most often by husbands (Hosken, 2001:1).

The ecclesiastical position of women is of particular interest in this regard. In the majority of Christian traditions women have inferior positions with regard to official duties. The following examples proof the point: The Roman Catholic tradition has a long tradition of gender inequality largely due to the influential legacy of Augustine and Aquinas. Since the papacy of Leo XIII, Pius X and later the council of Vatican II, the social position of women started to improve for the better. In the document Pacem in Terris (1963), Pope John XIII acknowledged that women rightly demand the rights and duties which belong to them as human persons both in domestic and public life (Walf, 1990:38). However, the ecclesiastical position of women has not changed. Even as late as 22 January 1977, the Holy See contended that Christ established a bond between maleness and the priesthood which could not be altered. This is still the position.

In the Eastern Orthodox tradition the bishop or priest visibly represents Christ in the continuing actualisation of the Eucharist that looks towards and proposes the Kingdom. If the bearer, the icon and the minister of this unique priesthood is a man and not a woman, it is because Christ was a man and not a woman. Women are thus excluded from the priesthood because Christ was a man (Gelerui, 1990:59).

In many sectors of Protestantism women are ordained in the particular offices, but there are still differences of opinion about the issue between conservative and moderate churches in this tradition (see in this regard Hauke, 1982:45; Field-Bibb, 1990:63). In the charismatic movement and the pentecostal revival movement, male dominance in the ministry of preaching is widely accepted and promoted. All these examples prove the argument that the idea of the inferiority of women are still nurtured in some pockets of Christianity and spills 
over in violations of the human rights of women in the socio-political domain.

A second manifestation of the violation of the human rights of women can be found in Islamic extremism. The extremist Muslim states such as Saudi Arabia, Libya, Pakistan, the former Taliban in Afghanistan, Iraq and Iran, which emerged since the Iranian revolution in the 1970s, are perhaps the most radical exponents of the abuse of the human rights of women. These governments rule with arbitrary power and the individual has to live by the mercy of the state. The state enforces the Shari'a (laws derived from the Qur'an), the Sunnah (normative practices associated with the prophet), the ljma (the consensus of the community) and the ljtidad (the counsel of judges on a particular case) in a strict manner. Within Muslim discourse, Shari'a designates the rules and the regulations governing the lives of Muslims, derived in principle from the Qur'an and the hadith. Hadith is used for the tradition being an account of what the prophet said or did, or of his tacit approval of something said or done in his name. Tradition is to be considered second in authority to the Qur'an. All these sources are interpreted in such a way that it aggravates the inferiority of women in all spheres of society (Vorster, 2004:184).

Abuses of women's rights in these countries range from the rejection of the notion that a woman can be considered as a juristic person by law to the impossibility for women to file for a divorce in court, the death penalty for women who committed adultery and the tacit approval of the so called honour-killings of women.

At the sessions of the Commission for Human Rights of the United Nations since 2000 the following additional violations of women's rights in these countries were tabled by members of the Commission as well as non-governmental organisations with international standing: women cannot own land or inherit anything from the estate of a relative or anyone else; women are not allowed to own or even drive a car; may not appear on the street without the presence of a male relative; must veil themselves and are heavily punished if they refuse (Nafisi, 2003:6-7).

Thirdly the manifestations of abuses of females in African traditional societies also can be mentioned. They are to a larger or lesser degree generally present in especially the poor and marginalised African societies. Women in Africa complain that they are victims of twofold oppression, namely by the remnants of the earlier colonialism and by the traditional African cultures. Colonialism deprived 
them of political and social rights, submitted them to slavery, excluded them from development and condemned them to extreme poverty. Due to the inferior position of women, it is fair to speak of a feminisation of poverty in Africa as in other parts of the developing world.

Taking the differences in African societies into account, it is fair to say that the position of women is for the most part inferior. They ordinarily have no legal status and are equal to children in this respect (Nwachuku, 1992:232). In the customary laws of some African cultures women are not allowed to own land and they are obliged to nurture the land of their husbands. Other examples of abuse are genital mutilation because of the custom of circumcision and the fact that they are not expected to refuse sexual intercourse with a man because of their inferior position. Recent research has revealed that in Southern Africa 33\% of women is HIV positive. This alarming situation can be ascribed to their inferior position in society.

African representatives at the United Nations claim regularly that Africa is changing, and at first sight it seems that the position of women are changing for the better. However, Nwachuku (1992:234) calls this notion a paradox and a dilemma because, while African society is rapidly changing its structures in principle, yet in practice the same society expects the powerless, like women, to remain unchanged in their traditionally prescribed roles and functions.

Ideologies of intolerance can also be highlighted as a contemporary human rights concern. Just as the surging religious extremism, ideologies of intolerance can also be held responsible for many violations of human rights. Among these are the still prevalent and troubling influences of ideologies promoting racism and xenophobia. In order to understand the contemporary use of the concept of racism, Marger's (1994:7) exposition of the term is of great value. In his view racism can be seen as a belief system or ideology that is structured around three basic ideas, namely:

- Humans are divided naturally into different physical types.

- Such physical traits as they display are intrinsically related to their culture, personality and intelligence.

- On the basis of their genetic inheritance, some groups are innately superior to others.

In sum, according to Marger, racism is the ideology which teaches that humans are subdivided into hereditary groups that are innately 
different in their social behaviour and capacities and can therefore be ranked as superior or inferior. The presumed superiority of some groups and inferiority of others are subsequently used to permit the unequal distribution of the society's resources, specifically, various forms of wealth, prestige and power.

The term racism can also be used to describe "bias" and intolerance between groups other than racial groups, such as ethnic and religious groups. Schutte (1995:18) says that ethnic groups can construct themselves on the basis of language, religion, culture, descent, or a combination of these and other features. An ethnic group may even shift the basis on which it constructs its identity from one feature to another. Historical ethnic groups may merge and found their solidarity on a new basis. Racism can pertain to Jews, Italian Americans, Northern Irish, Catholics or French Canadians as much as to African Americans, North American Indians or other more physically salient groups (Marger, 1994:28).

The common denominator in the ideology of racism and what is termed as ethnocentrism is the consciousness of the destination and tension between us as the "in group" and them as the "out group". With the "we feeling" and subsequent solidarity in the own group as measurement, a group can have the tendency to judge other groups by the standards and values of their own. According to Marger $(1994: 15)$ this tendency produces a view of one's own group (the "in-group") as superior to others (the "out-group").

This ideology of intolerance manifests itself in social stratification where one group seizes power and use the machinery of the state to oppress other groups. A clear example of such a structural racism was National Socialism in pre-war Germany and apartheid in South Africa. Nowadays this phenomenon appears in governments controlled by certain ethnic groups at the expense of others, such as in the former Yugoslavia, Israel, Rwanda, Burundi, Sudan and other African states. The intolerance has resulted in cruel wars of ethnic cleansing and many regional conflicts which endangered global peace.

Another ideology of intolerance is xenophobia, which is also rising in many regions due to the growing tendency of migration. In spite of the limitations of the term, xenophobia is an emerging social and human rights issue in the contemporary world because of migration and forced displacement of people. Migration and subsequent xenophobia has become a feature of the international reality that cannot be ignored in reflection on human rights (Pieterse, 2000:51). 
Due to this reality, several countries have become prone to xenophobic actions. Xenophobia has in recent years been responsible for the reinstatement of policies with the undercurrent of racism. These policies are formulated to resist immigration by people from other racial or ethnic groups.

The main manifestation of xenophobia is collective fear and subsequent aggression by a community against migrants. Xenophobia can be seen as racism in its broadest meaning and it is driven by the same factors. Eventually, as in the case of racism, it results in prejudice, stereotyping, bias and discrimination. Religion and culture play an important part in xenophobia. Müller (1999:69) refers to the fact that religion and culture are strategies of meaning and practice rather than timeless and fixed substances, religions or cultural arguments can be construed that portray foreigners as being inferior, less deserving of right or humanity, reducible to a common negative, legitimately expendable. The fear usually results in inhuman policies by hosting governments and various forms of aggression by the citizens. Various occasions are documented of the use of inhuman methods and illegal and excessive force in the process of deportation of asylum-seekers and illegal immigrants (see in this regard Webber, 1997:22-23).

Lastly, the growing concern about the destruction of the ecosystems can be mentioned. History, and especially modern times, has been marked by a process that can be termed as ecocide. Broswimmer uses this term to refer to the most recent crisis of the mass extinction of species. With the term ecocide he refers to acts undertaken with the intention of disrupting or destroying, in whole or in part, a human ecosystem. In addition to his reference to intentional acts the term can also be used to describe irresponsible acts which destroy ecosystems, such as the waste of toxic materials and pollution of natural resources. Ecocide refers thus to any form of violation of ecological rights, generally referred to as third generation rights.

Broswimmer (2002:218) provides a valuable and well documented periodisation of ecocide. He indicates that three historical phases can be identified in the aetiology of ecocide. The first critical step in the aetiology of the present disaster occurred some 60000 years ago when homo sapiens begin to use extra somatic energy. The second critical step in the aetiology of ecocide was the establishment of sedentary agriculture, culminating in the Neolithic revolution some 10000 years ago. The third critical step in the aetiology of ecocide was the rise of modernity. McCormick and Connors (2002:218) roughly use the same periodisation with reference to 
Rasmussen. They use the following terminology: the land-based age, the industrial age and the ecological age.

Current trends of globalisation are another contributing factor to modern ecocide. Transnational companies have become so big that their international sales often exceed the Gross Domestic Produce of entire nations. The mere magnitude of these companies makes it virtually impossible for governments to contain them. It becomes difficult to enforce laws regarding ecological conservation onto these companies which numbers around 87000 according to a United Nations investigation.

These factors make the destruction of the habitat of all living species in the modern age evident. Deforestation continues at an alarming rate and global warming changes climates. McCormick and Connors (2002:215-216) refer to studies that indicate clearly that the 1990s was the warmest decade on record, that the earth's surface temperature has increased about one degree Fahrenheit in the last century and that this situation has accelerated since 1979. Humankind can expect even more rapid warming trends and the doubling of carbon dioxide levels in this century. This will inevitably lead to floods, droughts and heat waves. Every year consumers and industries burn an amount of fossil fuels that took a million years to produce. The expectation is that the world will run out of petroleum in forty years and natural gas in sixty years.

These four human rights concerns dominate the contemporary human rights discourse as the agendas of the Human Rights Council of the United Nations indicate. Can a deontological Christian ethics be of any assistance in such a discourse by offering sustainable solutions? To answer this question the status of deontological Christian ethics today have to be considered.

\section{The status of deontological Christian ethics today}

In the years after the origination of the Universal Declaration of Human Rights, deontological Christian ethics was increasingly ignored as a relevant role player in the field of the ethics of human rights. This tendency can be ascribed to the modernism of the postenlightenment era in Western history. Modernism shifted deontological Christian ethics with its deontological theory to the sphere of the religious and opted instead for a social "rights based" utilitarian ethics. 
However, over the past few decades this marginalisation of Christian ethics faded away and societies developed a new interest in what deontological Christian ethics has to offer in the ethics of human rights. This new development can be ascribed to the paradigm shift from modernism to postmodernism that characterised Western thought and culture. According to the well-known thesis of Kuhn (1970:viii) a paradigm can be defined as universally recognised scientific achievements that for a time provided model problems and solutions to a community of practitioners. Modernity was such a paradigm because it determined Western thought and culture for two centuries. When such a paradigm becomes unable to provide solutions to a community of practitioners, it has to make way for a new paradigm.

A paradigm shift thus occurs when the old paradigm becomes unable to provide solutions for new realities and problems (Kuhn, 1970:111). Modernism became questionable because of the devastating effects of World War II. Western communities searched for solutions for the post-war chaos and the turmoil created by the cold war, the nuclear threat, the dangerous arms race and the current ecological disasters. Modernism is increasingly seen as a moral failure because of the inability of utilitarian ethics to provide solutions for new realities. Soon the new paradigm emerged which became known as postmodernism. Kuhn's thesis is well known and widely accepted as a valid explanation of the emergence of this new postmodernist paradigm in Western civilisation.

According to Bauman (2004:238) the term postmodernism renders accurately the defining traits of the social condition that emerged throughout the affluent countries of Europe and European descent in the course of the twentieth century, and took its present shape in the second half of the century (see also Gill, 1997:15). This condition entered Western culture in the latter part of the twentieth century. The latter part of the twentieth century became thus known as the time of a paradigm shift from modernism to postmodernism.

The term postmodernism became popular after the publication of Lyotard's book, La condition post-modern: rapport sur le savoir, in 1979. Since then virtually all disciplines in the humanities and social sciences accepted the reality of a new emerging postmodernist paradigm which implied a new direction in Western culture. According to Lyotard (1991:23) the time of the metanarratives, which were the strength of modernism has elapsed. He defines the emerging postmodernism as incredulity towards these metanarratives (the Enlightenment, Christianity and great Western institutions). He con- 
tends that the narrative function is losing its functors, its great hero, its great dangers, its great voyages, and its great goal. It is being dispersed in clouds of narrative language elements - narrative but also denotative, prescriptive, descriptive and so on. Conveyed with each cloud are pragmatic valencies specific to its kind. Each of us lives at the intersection of many of these (Lyotard, 1991:24). Postmodernism is thus a new condition which questions the suitability of the metanarratives of the past.

For the purposes of this article it is not necessary to enter into a thorough explanation of the total philosophy of postmodernism. However, one feature of postmodernism should be discussed regarding the debate dealing with the relevance of deontological Christian ethics today. Postmodernism posits that truth is relative and that moral codes can never be seen as fixed codes. In his incisive explanation of this new condition Gill (1997:17) says that the notion of secular, rational progress implicit in much of the Enlightenment tradition has become increasingly implausible.

According to him postmodernism claims that no single metanarrative can hope to secure consensus in a postmodern culture. Both secular rationalism and Christian belief are now seen as faith positions held variously by individuals who lack any common metaposition. Instead of relying on, and promoting the great metanarratives of the past, postmodernism presents the credibility of pluralism.

Furthermore, postmodernism states that reason can not claim the truth over and above religion. Just as modernism questioned religion, postmodernism questions reason and the "reasonable claim to truth". Truth is relative. More than one truth can be plausible at the same time. More than one moral norm can be acceptable in the same situation. Therefore, postmodernism rejects the idea of absolute truths, principles and norms. It professes the validity of diversity and relativity in the definition of truth and moral virtues. Relativism replaces absolutism of certain invariable truths and norms. Humankind has to accept that diversity and pluralism are facts of life. Küng (1991:20) asserts that humankind moves in the direction of a post-ideological culture which in future will be a culture more orientated on an overall plurality.

Relativism poses certain serious questions to Christian belief as a "truth-seeking faith", but at the same time renders a new validity to this belief. Just as postmodernism is concerned with the subjects and the validity of their presuppositions in doing science, it is also concerned about people and their feelings, emotions and spirituality. 
According to Küng (1991:20) the paradigm shift from modernism to postmodernism entails a development from a technocracy which dominates people to a technology which serves the humanity of men and women. It also entails a shift from an industry which destroys the environment to an industry which furthers the true interests and needs of men and women in accord with nature. Postmodernism is concerned about the emotional and spiritual well-being of human beings in the strict legalistic, agnostic and technocratic society which it regards as the heritage of the modernist paradigm. In this way postmodernism restored the plausibility of a deontological Christian ethics.

With the new challenges posed by postmodernism to systematic theology and hermeneutics, came a new interest in deontological Christian ethics. The new postmodern society brought Christian ethics, among other religious ethical positions, back to the "market square of ideas". This development is also true of the current human rights debate. At a panel discussion at the United Nation's Council for Human Rights' celebration of the 60th anniversary of the Universal Declaration of Human Rights in 2008, eminent human rights specialists maintained that human rights can not be defined as universal as long as religious perspectives are not incorporated in the human rights discourse (United Nations, 2008). This discussion revealed that scholars are again willing to listen to the transposition of, inter alia, core Biblical ethical topics into moral obligations, applicable to the disturbing socio-political realm of contemporary societies. At the same time it challenges Biblical ethicists to enter the human rights debate in a plausible way and to shed new light on contemporary social problems. These new possibilities for Biblical ethical reflection can be illustrated when the major contemporary human rights concerns discussed in section 1 are highlighted and approached from the angle of prominent Biblical topics. Such a reflection serves as an example of a possible deontological Christian ethical approach to human rights concerns. In the following subsection certain Biblical topics are addressed to indicate how they can be transposed into suitable tools to deal with these concerns in a plausible way.

\section{Relevant Biblical themes for contemporary ethical reflection}

A first concept that needs to be transposed in a contemporary sociopolitical environment is creation and creational integrity. Since the publication of the influential article by White (1967:1303; see also 
Barr, 1974:48-75) many scholars agreed with him in his assessment that Christianity is partly to blame for the ecological crisis as it developed in modernity. He blames the story of creation by saying that humankind named all the animals, thus establishing its dominance over them. He maintains that God planned all of this explicitly for humankind's benefit and rule. No item in the physical creation had any purpose save to serve humankind's purpose. He then concludes that in its Western form, Christianity is the most anthropocentric and ecocidal religion the world has seen (White, 1967:1305). Loader (1987:9) also concludes that Christianity created a dualism between humankind and nature, and nature was relegated to something of a second degree. As is the case with White, he maintains that Christianity does have a burden of blame to bear for what has happened to nature.

Moltmann (1985:33) paved the way for a new interpretation of creation where the emphasis is not on dominance, but on conservation. He stresses the stewardship character of human existence over and against the utilitarian principle of modern science by emphasising the immanence of God in creation. According to this interpretation, science has boundaries because its primary task is to serve the integrity of creation. Such an interpretation of creation will pave the way for a deontological Christian ethics which will act as an agent for ecological concerns because it stresses the obligation to preserve over and against the consumerist utilitarian approach of modernism. This approach indicates how deontological Christian ethics can develop the ability to provide plausible directives to address these concerns.

The doctrine of the imago dei is another Biblical topic that has huge potential to nurture moral directives for action today when it is transposed into a socio-political context. God created people to live in a relationship of mutual love and care. This relationship is expressed in the creation of humankind in the image of God. The imago dei has direct implications for a Christian anthropology. Since the Reformation several theologians spelled out these implications although it remained a highly underdeveloped concept in this tradition. The imago dei teaches the inherent human dignity of all people which should be respected by fellow human beings and social institutions.

Calvin (2008, Institutes 1.11.2.147) did not use the term "human dignity". However, he stressed the worthiness of the human being. In his view the creation of humankind on the "sixth day" is important to note because God created firstly the dwelling place of people, 
then the angels to act as protectors of humankind. These actions were the prelude to the creation of humankind. Humankind was bestowed with a certain status. Humans are the most precious and worthy to look at and this fact is proof of God's righteousness (Calvin, 2008, Institutes 1.15.1.172). But the biggest quality of humankind is its likeness to God which seats in the intellect and in the abilities of the "soul" (Calvin, 2008, Institutes 1.15.4.179). In spite of humankind's alienation from God due to the fall, the imago dei has not been destroyed. People maintain the dignity of their creation and all the responsibilities and privileges flowing from this inherent dignity remain intact.

Deontological Christian theologians since the Reformation furthered Calvin's argument of the dignity of humankind - especially in the twentieth century with the emergence of the idea of human rights against the background of the human rights abuses in World War II. Barth (1950:116; see also Westermann, 1978:344) introduced the view that the imago dei is a relational concept. The imago dei is an expression of God's willingness to enter into a relation with humankind. Man became a relational being and in their expression of relations of love and care people expresses their basic dignity. In other words people's ability to express humaneness is a sign of the imago dei. That is the reason why God forbids manslaughter and why preservation of life is so important in the Old Testament laws (Barth, 1950:344). The purpose of human conduct is to preserve and protect life and everything it entails, such as humaneness, compassion, caring and social concern.

The prominent Dutch theologian Berkhouwer (1957:34) fostered this idea and added that due to the imago dei and the atonement in Christ a human being becomes man of God and receives as such the ability to strive after the justice of the kingdom of God. The main ethical implication of the imago dei is that it sets the possibility for humans to be free from any form of slavery and lack of freedom due to the blemishes of sin and feelings of guilt.

Moltmann (1997:129) also reflects on the ethical implications of the imago dei for a socio-political environment. He maintains that the concept is a theological concept with clear ethical implications. The concept should be explained in its close relationship with the imago Christi and Gloria Dei est homo (Moltmann, 1985:216). The doctrine of the basic dignity of humankind as it is expressed in the imago dei can be developed further by Biblical themes such as the life-giving work of the spirit of God. Brueggemann (1999:51) pave the way for such a development by saying that God's very life is breathed into 
the sinner; something of God's own self becomes an integral part of human identity, enabling life to move from God out into the larger world. All humans are gifted with the creational gifts of the Spirit (Westermann, 1978:450). These gifts enable humans to fulfil their calling to be stewards of creation.

The imago dei has thus everything to do with human relationships the relation between God and humankind and between humans. Humans are created as relational beings. They relate to God, to each other and to the rest of creation. They are representatives of God in this world to care for his work as stewards. The imago dei should be manifested not only in a few human characteristics, as early Christian theology argued, but in the totality of human existence.

The Biblical teaching of human dignity, founded in the doctrine of imago dei has direct implications for all situations where human relations are at stake. The concept offers an answer to the violation of the human rights of women and a positive response to the current ideologies of intolerance. It teaches humankind that all people should be treated as bearers of a human dignity that is granted by God. This basic human dignity bridges all forms of divisions and inabilities to live in peace. It lies down the rules for reconciliation in the midst of intolerance, racism and xenophobia and gives content to the responsibility of people to live in harmony with people of all faiths and persuasions. Therefore, Christians as testifiers of human dignity have to be agents of reconciliation, peace and healing in all spheres plagued by distorted relations. The Biblical idea of imago dei, as it is argued and applied in the Christian tradition, has thus concrete implications for Christian anthropology and social ethics which is deontological in nature.

In recent Christian theological reflection, the relevance of the concept of the Kingdom of God, as an immanent historical reality, for socio-political ethics has been investigated especially in the Dutch Reformed tradition. This research revealed that the concept of the kingdom is another Biblical topic that can be transposed into a useful tool in the ethics of human rights. In this process the work of the New Testament scholar Ridderbos (1962) was of special importance. He and other theologians in this tradition maintained that the Biblical notion of a "coming kingdom" has explicit implications for the renewal of society and for social justice.

In essence, the kingdom is all about the reign of God and his restorative rule over the whole creation. The Old Testament proclaims the 
reality of this rule. The New Testament proclaims the rule of God as it is manifested in the coming of Christ and the formation of the people of God. The reign of God is a present and future reality. Küng (1967:56) calls it futurist-presentist eschatology. This reign has already been manifested in the coming of Christ, but will be revealed in its completeness at the end of time. The whole history of the covenant is an indication of the historical reality of the kingdom and thus of the restorative work of the triune God. God's rule establishes various signs of the kingdom in this fallen reality - especially in the form of people acknowledging the rule of God and co-operating in the proclamation of this divine rule by acts of justice and promotion of peace.

The idea of the kingdom thus provides a point of departure and motivation for people to be involved in acts of reconciliation, peaceseeking and justice. Proclaiming the kingship of Christ in all spheres of life entails that the morality of the kingdom, as expressed in the sermon on the mount, has to be realised in socio-political terms. This morality can be described with the term reconciliation. Reconciliation is an important Christian concept. This concept describes the multidimensional result of the reconciliation of humanity as a result of the atoning sacrifice of Christ. It is the counter force against the distorting and de-stabilising working of evil. It enables humans to reconcile with God, with fellow human beings and erect new relations with the environment. The concept of the kingdom can rightly be seen as the foundation of humankind's obligations to promote reconciliation where divisions disturb peace.

Nowadays the concept forgiveness is another Biblical topic widely investigated in, inter alia, the human rights environment. It is a much used term in the human rights discourse due to the many Truth Commissions that came into being in countries with political transitions. However, the concept is actually a prominent Biblical topic. Gestricht and Zehner (2001:330) compiled a useful list of the various uses of the concept in the Biblical text. This list reveals the richness of the concept as well as the fact that the topic is deeply embedded in Christian theology. It is fair to say that forgiveness is among the most important topics of the Christian message. The atonement of Christ brought about the gift of forgiveness of God and initiates the command to forgive in interhuman relations and to restore communion.

What is the theological meaning of the call to forgiveness according to these various usages of metaphors, technical terminology, sym- 
bolisms and phrases in the Biblical message? An "ethics of forgiveness", applicable to a contemporary socio-political transition, can be developed when the variety of explanations is investigated within the framework of the concept of the kingdom of God. Such an investigation reveals that the resurrection of Christ entails that God offers to all the possibility of living in peace by the power of forgiveness (Hauerwas, 1983:89). Forgiveness leads to reconciliation and the reconciliation between people, amidst the brokenness caused by evil, manifests the new reality of the kingdom. In other words, the peaceable kingdom is, among others, realised by the forgiving acts of humans. Every act of forgiveness symbolises this new reality because it constitutes a new beginning in a particular relation. Where sin distorts communion, forgiveness restores communion (Jones, 1995:59). As such it displays the morality of the kingdom.

The ethics of forgiveness has direct implications for social justice. Such an ethic reveals that in spite of the grace and joy embedded in acts of forgiveness, forgiveness cannot be unconditional. The new reality created by forgiveness can emerge only when certain conditions are met. Firstly, human forgiveness requires true repentance. Repentance and forgiveness are central in the Christian way of life. It is true of Christians in their calling in all spheres of life either in the macro sphere of politics or in the micro sphere of marital relations.

Secondly, the injustice of the damaging social conditions must be confessed. Jones (1995:19) rightly states that repentance and confession must be practiced in specific and concrete ways, as part of the larger craft of forgiveness, if they are to result in that truthfulness that empowers people for faithful discipleship to Jesus Christ. His argument roots in Bonhoeffer's view about the cost of discipleship which is still a powerful reminder of what true forgiveness entails. Christ's sacrificial and atoning death makes self knowledge and repentance possible, but repentance and confession are conditions for forgiveness. Otherwise forgiveness becomes cheap. Smit (2007: 315) makes a good case for the need of interpersonal and intercommunal confession, such as was done in the proceedings of the South African Truth and Reconciliation Commission. People had the opportunity to confess to each other and to heal broken relations by mutual forgiveness.

Thirdly, forgiveness requires social justice - a turn-about of the social conditions which caused the atrocities that should be forgiven and a rectification of the circumstances that caused the breaking down of relations. Transposed into a socio-political praxis this repentance should be manifested into a willingness to restore and to re- 
dress. Seen against the background of the South African context, whites for example, should admit that they were wrongly benefited by the system at the expense of black interests but this submission have to be contextualised in a willingness not only to restore the human dignity of black people but also to redress the socioeconomic injustices that were developed by apartheid. The willingness must be willingness to sacrifice and concrete deeds of sharing their wealth in an orderly and legitimate fashion.

Hauerwas (1983:90) reminds us that God made Christians agents of the history of the kingdom. Christians should therefore not only be active agents in the restoration of distorted relations but also whistle blowers whenever and wherever the table is set for new social injustices that may emerge. Forgiveness thus requires an ethos of "this may not happen again". The confessing person is the most able agent of this ethos, because the guilty party is in the best position to illuminate the causes of the unjust worldview and system.

Fourthly, repentance, confession and the implementation of social justice must be answered with forgiveness, which entails a closing down of all enmity, with an elimination of bitterness and a willingness to start the new relations with a clean slate. "Forgiveness" that still nurtures blame, hate speech and continuing references to the uneasy past can not be described as a virtual image of God's forgiveness and a sign of the new reality that can be brought about by the gift of forgiveness. These are some of the implications of the Christian concept of forgiveness when transposed into an ethics of forgiveness applicable in the contemporary human rights environment.

\section{Conclusion}

This article endeavoured to explain how Christian reflection about socio-political injustices has regained a plausible position in contemporary global reflection regarding human rights concerns. The new position is a result of the paradigm-shift from modernism to postmodernism. Furthermore, the discussion posits the thesis that, in this new metatheoretical environment, topical Biblical concepts can, and should be transposed to the contemporary socio-political realm in order to address these concerns. As examples I considered such a transposition of creation, imago dei, the kingdom of God, and forgiveness. Much more can be said about the socio-political relevance of these concepts. Many other concepts can be added to this list such as the Biblical idea of life, eschatology, hope, reconciliation, covenant and holiness. However, the main argument of this reflec- 
tion is that deontological Christian ethics can make a positive contribution in solving contemporary human rights concerns. In such a way deontological Christian ethics can perform a valuable and plausible duty in the contemporary human rights discourse.

\section{List of references}

ANTOUN, R.T. 2001. Understanding fundamentalism: Christian, Islamic, and Jewish movements. Oxford: Altamira.

BARR, J. 1974. Man and nature: the ecological controversy and the Old Testament. (In Spring, D. \& Spring, E. Ecology and religion in history. New York: Harper \& Row. p. 48-75.)

BARTH, K. 1950. Die kirchliche Dogmatik: die Lehre von der Schöpfung. Bd. 3(4). Zollikon-Zürich: Evangelischer Verlag.

BAUMAN, Z. 2004. A sociological theory of post modernity. (In Drolet, R., ed. The postmodernism reader. London: Routledge. p. 234-249.)

BERKHOUWER, G.C. 1957. Dogmatische studiën: de mens het beeld Gods. Kampen: Kok.

BROSWIMMER, F.J. 2002. Ecocide: a short history of mass extinction of species. London: Pluto.

BRUEGGEMANN, W., ed. 1999. A theological introduction to the Old Testament. Nashville: Abington.

CALVIN, J. 2008. Institutes of the Christian religion. Trans. by $\mathrm{H}$. Beveridge. Peabody: Hendriksen.

CAMP, R.L. 1990. Women in the Catholic Church. Catholic historical review, 76(3):506-526.

CUPITT, D. 1999. Post-Christianity. (In Heelas, P., ed. Religion, modernity and post-modernity. Oxford: Blackwell. p. 218-232.)

FIELD-BIBB, J. 1990. Women towards priesthood, ministerial politics and feminist praxis. New York: Cambridge.

GELERUI, C. 1992. The orthodox church and the question of admitting women to the ordained ministry. (In Limouris, G. The place of women in the Eastern orthodox church and the question of the ordination of women. Katerni: Tertios. p. 39-59.)

GERAUDY, G. 1990. Human rights and Islam: foundation, tradition, violation. Concilium, 1990(2):46-60.

GESTRICHT, C. \& ZEHNER, J. 2001. Forgiveness. (In Fahlbusch, E., ed. The Encyclopaedia of Christianity. Leiden: Brill. p. 330-334.)

GILL, R. 1997. Moral leadership in a post-modern age. Edinburgh: Clark.

HAUERWAS, S. 1983. The peaceable kingdom. Notre Dame: University of Notre Dame Press.

HAUKE, M. 1982. Die Problematik um das Frauenpriestertum vor der Hintergrund der Schöpfungs- und Erlössungsordnung. Paderhorn: Bonafacius-Druckerei.

HOSKEN, F. P. 2001. Editorial. Women's international news network, 27(4):1.

HUNTINGTON, S.P. 1996. The clash of civilizations and the remaking of the world order. London: Simon \& Schuster.

JONES, L.G. 1995. Embodying forgiveness: a theological analysis. Grand Rapids: Eerdmans. 
KUHN, T.S. 1970. The structure of scientific revolutions. Chicago: University of Chicago Press.

KÜNG, H. 1967. Die Kirche. Freiburg: Herder.

KÜNG, H. 1991. Global responsibility: in search of a new world ethic. London: SCM.

LOADER, J.A. 1987. Image and order: Old Testament perspectives on the ecological crisis. (In Vorster, W.S., ed. Are we killing God's earth? Ecology and theology. Pretoria: University of South Africa. p. 6-28.)

LYOTARD, J.F. 1991. The post-modern condition: a report on knowledge. Manchester: Manchester University Press.

MARGER, M.N. 1994. Race and ethnic relations: American and global perspectives. Belmont: Wordsworth.

MARTY, M.E. \& APPLEBY, R.S., eds. 1991. Fundamentalisms observed: a study conducted by the American Academy of Arts and Sciences. Chicago: University of Chicago Press.

MCCORMICK, P. \& CONNORS, R.B. 2002. Facing ethical issues, dimensions of character, choices and community. New York: Paulist Press.

MOLTMANN, J. 1985. Gott in der Schöpfung. Munich: Christliche Verlag.

MOLTMANN, J. 1997. The original study paper: the theological basis of human rights and of the liberation of human beings. (In Miller, A.O.A. Christian declaration of human rights. Grand Rapids: Eerdmans. p. 129-143.)

MÜLLER, H. P. 1999. Encountering recent African migrants and immigrants to South Africa: towards understanding the role of religion and culture in the reception of recent African migrants and immigrants to South Africa. Scriptura, 68(1):67-73.

NAFISI, A. 2003. The veiled threat. New republic, 220(8):6-7.

NWACHUKU, N.D. 1992. Women in Africa in the process of adjustment and change. Evangelical review of theology, 16(3):232-250.

PIETERSE, M. 2000. Foreigners and socio-economic rights: legal entitlements or wishful thinking? Tydskrif vir hedendaagse Romeins-Hollandse reg, 63(1):51-61.

RIDDERBOS, H. 1962. De komst van het koninkrijk. Kampen: Kok.

SCHUTTE, G. 1995. What racists believe: race relations in South Africa and the United States. London: Sage.

SMIT, D.J. 2007. Essays in public theology: collected essays. Cape Town: Sun Press.

UNITED NATIONS. 1996. The United Nations and the advancement of women 1945-1996. Documents 106 and 137. New York: United Nations.

UNITED NATIONS. 2008. Panel discussion in commemoration of the sixtieth anniversary of the Universal Declaration of Human Rights at the thirtieth session of the Council 2008. Geneva: United Nations.

VORSTER, J M. 2004. Ethical perspectives on human rights. Potchefstroom: Potchefstroom Theological Publications.

VORSTER, J.M. 2008. The challenge of contemporary religious fundamentalism. Pretoria: Church History Society of South Africa. (Book Series, 1.)

WALF, K. 1990. Gospel, church law and human rights. Concilium, 1990(2):3445.

WEBBER, F. 1997. Governing racism: the corruption's of the executive. Race and class, 39(1):19-35. 
WESTERMANN, C. 1978. Theologie des Alte Testaments in Grundzügen. Göttingen: Vandenhoeck \& Ruprecht.

WHITE, L. 1967. The historical roots of our ecological crisis. Science, 155(3767):1302-1307.

\section{Key concepts:}

\section{creation}

deontological ethics

ecocide

femicide

imago dei

\section{Kernbegrippe:}

imago dei

deontologiese etiek

ekovernietiging

skepping

vroue, diskriminasie en geweld teen 